\title{
Students' Capabilities in Essay Preparation Related To Competency and Learning Objectives through Course Evaluation Education of Biology Teacher
}

\author{
Makrina Tindangen \\ Department of Biology Education, Faculty of Teacher Training and Education, Mulawarman University, Indonesia \\ makrina_tindangen@yahoo.co.id
}

\begin{abstract}
The ability of students in preparing essay questions. Based on these questions, the purpose of this study is to find out what students are driving at the time of procurement about the essay and what the lecturer's efforts to overcome the problem. To achieve the purpose of this study then the research method used is descriptive research and then analysis of data used is categorization of learning outcomes in accordance with the indicators of making the essay in the form of a table that contains the percentage of student achievement related to the making of essay. The next step is to give interpretation or meaning. The results showed $80 \%$ of students have problems with Conformity with Learning Objectives / Indicators, $80 \%$ of students have Problems Compliance with Learning Materials, $80 \%$ of students have a Level of Difficulties Referring to Cognitive Ability $80 \%$ of students use Bahasa Indonesia Baku, $80 \%$ of students Troubled with Time Allocation For Working, $80 \%$ of students are related to the ability of Student Thinking Based on the results of the research, it is read in the lecture material of the lecturer to facilitate the students by descending the question and other forms of evaluation by utilizing the assessment rubric through the presentation activity in the lecture.
\end{abstract}

Keywords-essay; competency; education evaluation

\section{INTRODUCTION}

Curriculum is now applied in SMA and SMP namely Curriculum 2013 (requires a thorough assessment of students' abilities covering aspects of cognitive (ability), psychomotor (skills), and affective (attitude), so that should be the candidate master of competency way of assessing and developing assessment instrument learning. The course Evaluation education have an important role in preparing students to implement PPL and prepare a thesis in demand to have the ability to develop learning evaluation tool. Administration results indicate that students have the ability to develop the instrument of assessment of learning is still low. It can be seen from the results lectures that have not been satisfactory because the average new value reached the category less [1-3].

In accordance with Government Regulation No. 74 of 2008 on teachers that teachers are professional educators with the main task of educating, teaching, guiding, directing, training, assessing and evaluating learners in early childhood education formal education, basic education and secondary education .
Government Regulation of the Republic of Indonesia Number 74 of 2008 Article 3 that competence is a set of knowledge, skills and behaviors that must be owned, experienced, mastered and actualized by teachers in performing professional duties include: pedagogic competence, personality competence, social competence and professional competence. competencies that must be mastered by the teacher is pedagogic competence is the ability of teachers in learning management of learners, some of which consists of evaluation of learning outcomes, and development of learners to actualize various potentials. Many students face difficulties in planning evaluations in order to properly evaluate student learning outcomes [4]. Examples of problems faced by students is, less can build essay problem based on the criteria of the question. This shows that the evaluation component of other learning outcomes is also problematic for the students. The components of learning outcomes by taxonomy bloom is cognitive, affective and psychomotor. Based on the problems experienced by the student in learning subjects' evaluation then as a lecturer has an obligation to solve the problem with research.

Based on the above background then the formulation of the problem of this study are (1). What problems faced by students related to the preparation of essays in accordance with the competencies and objectives?, and (2). What efforts do lecturers to improve students' ability in preparing essay questions and evaluating student learning outcomes?

Based on the problem, the purpose of this independent research is as follows: (1). To find out what problems faced by students related to the preparation of essays in accordance with the competence and objectives, and (2). To find out what efforts made by lecturers in order to improve students' ability in preparing essay questions and evaluating student learning outcomes.

\section{Methodology}

The type of research used is descriptive research type. The type of descriptive research is research that aims to find relationships on the facts and provide interpretation or interpretation of these facts [5].

This research was conducted for 6 months, starting from April to September 2015, for all students in the lecture room of 
Biology Education, Faculty of Teacher Training and Education of Mulawarman University, Samarinda, East Kalimantan.

In this study consists of two variables, namely independent variables and dependent variables. The independent variable is the preparation of essay related issues of purpose and evaluation, while the dependent variable is the ability to prepare essays by students.

\section{A. Sample}

The sample in this research is batch Biology Education students. The sampling technique used is purposive sampling by paying attention to the students who take the lecture course of learning evaluation.

\section{B. Data collection technique}

Data in this research is obtained through an interview with lecturer, observation, done by observing the process of welding process of pre-school, and the task of planning and preparation (making) about essay based on taxonomy bloom.

\section{Data analysis technique}

The data analyzed in this research is the result of the students' ability in planning and making essay problems both before and after learning evaluation of education. The first data analysis is the categorization of capabilities in the form of tabulation, which contains the performance of the students achievement related to the planning and reporting of the results of project activities. The next step is to give interpretation or meaning.

\section{RESULTS AND DISCUSSION}

Based on research that has been done by analyzing students capabilities in the preparation of questions can be seen in the following Table I.

TABLE I. RESEARCH RESULTS RELATED TO PROBLEMS FACED BY STUDENTS IN PREPARING ESSAYS BEFORE THE LECTURE

\begin{tabular}{|c|c|c|c|c|c|}
\hline \multirow[b]{2}{*}{ NO } & \multirow[b]{2}{*}{ Criteria Assessment } & \multicolumn{4}{|c|}{ Assessment } \\
\hline & & Less $\%$ & $\begin{array}{l}\text { Enough } \\
\%\end{array}$ & $\begin{array}{l}\text { Good } \\
\%\end{array}$ & $\begin{array}{l}\text { Very } \\
\text { Good } \\
\%\end{array}$ \\
\hline 1 & $\begin{array}{l}\text { Conformity With } \\
\text { Learning Objectives / } \\
\text { Indicators }\end{array}$ & $60 \%$ & $26,66 \%$ & $13,33 \%$ & \\
\hline 2 & $\begin{array}{ll}\text { Conformity } & \text { With } \\
\text { Learning Materials } & \end{array}$ & $66,66 \%$ & $26,66 \%$ & $6,66 \%$ & \\
\hline 3 & $\begin{array}{l}\text { Has Levels of } \\
\text { Difficultness Referring to } \\
\text { Cognitive Ability }\end{array}$ & $50 \%$ & $33,33 \%$ & $16,66 \%$ & \\
\hline 4 & Using Raw Indonesia & $83,33 \%$ & $10 \%$ & $6,66 \%$ & \\
\hline 5 & $\begin{array}{l}\text { In accordance with Time } \\
\text { Allocation To Work }\end{array}$ & $83,33 \%$ & $13,33 \%$ & $3,33 \%$ & \\
\hline 6 & $\begin{array}{l}\text { Train Students' Thinking } \\
\text { Skills (Higher Thinking } \\
\text { Skills) }\end{array}$ & $66,66 \%$ & $20 \%$ & $13,33 \%$ & \\
\hline
\end{tabular}

TABLE II. RESEARCH RESULTS RELATED TO PROBLEMS FACED BY STUDENTS IN THE PREPARATION ESSAY AFTER THE LECTURE

\begin{tabular}{|l|l|l|l|l|l|}
\hline \multirow{2}{*}{ NO } & Criteria Assessment & \begin{tabular}{l} 
Assessment \\
\cline { 3 - 5 }
\end{tabular} & $\begin{array}{l}\text { Less } \\
\%\end{array}$ & $\begin{array}{l}\text { Enough } \\
\%\end{array}$ & $\begin{array}{l}\text { Veod } \\
\text { Good \% }\end{array}$ \\
\hline 1 & $\begin{array}{l}\text { Conformity } \\
\text { Learning Objectives / } \\
\text { Indicators }\end{array}$ & & $13,33 \%$ & $26,66 \%$ & $60 \%$ \\
\hline 2 & $\begin{array}{l}\text { Conformity With } \\
\text { Learning Materials }\end{array}$ & & $6,66 \%$ & $26,66 \%$ & $66,66 \%$ \\
\hline 3 & $\begin{array}{l}\text { Has Levels of } \\
\text { Difficultness Referring to } \\
\text { Cognitive Ability }\end{array}$ & $16,66 \%$ & $33,33 \%$ & $50 \%$ \\
\hline 4 & $\begin{array}{l}\text { Using Raw Indonesia } \\
5\end{array}$ & $\begin{array}{l}\text { In accordance with Time } \\
\text { Allocation To Work }\end{array}$ & $6,66 \%$ & $10 \%$ & $83,33 \%$ \\
\hline 6 & $\begin{array}{l}\text { Train Students' Thinking } \\
\text { Skills (Higher Thinking } \\
\text { Skills) }\end{array}$ & $3,33 \%$ & $13,33 \%$ & $83,33 \%$ \\
\hline
\end{tabular}

TABLE III. PROBLEM AFTER LEARNING PROCESS EVALUATION OF EDUCATION PROBLEM PREPARATION OF ESSAY OSAL

\begin{tabular}{|l|l|l|}
\hline NO & Criteria Assessment & Assessment \\
\hline 1 & Conformity With Learning Objectives / Indicators & $13,33 \%$ \\
\hline 2 & Conformity With Learning Materials & $6,66 \%$ \\
\hline 3 & $\begin{array}{l}\text { Has Levels of Difficultness Referring to Cognitive } \\
\text { Ability }\end{array}$ & $16,66 \%$ \\
\hline 4 & Using Raw Indonesia & $6,66 \%$ \\
\hline 5 & In accordance with Time Allocation To Work & $3,33 \%$ \\
\hline 6 & Train Students' Thinking Skills (Higher Thinking Skills) & $13,33 \%$ \\
\hline
\end{tabular}

Results of research related problems faced by students related to the preparation of essays in accordance with the competence and learning objectives before the evaluation process of education as shown in Table I, where $83.33 \%$ with very less category, $13.33 \%$ with good enough category and $3.33 \%$ with good category.

The results of this study illustrates that over $80 \%$ of students do not have a good understanding of the preparation of essays, things that are not understood by students related to the preparation of essay questions is in conformity with the goals / indicators of learning, conformity with learning materials, has a level of difficulty that refers on cognitive ability, using standard Indonesian language, in accordance with the time allocation to work, to train students' thinking ability (high-level thinking ability), Table II.

Problems faced by students related to the preparation of essays with the purpose of learning and indicators, especially on the lack of synchronization between the learning objectives as achievement of learning outcomes with material questions made, consequently matter does not measure what should be measured. In addition, the problems faced by students in the preparation of the essay problem is not adapted to the subject matter. This can happen because at the time of preparing the essay material does not refer to the purpose / indicator of learning.

Another thing that is still problematic is the essay matter that is made does not describe the level of difficulty so that the motion is only homogeneous that is high level cognitive or high level cognitive only. Language problems also occur in the students when composing a problem where the results of the 
question made confusion for the students or people who will answer it because it cannot find what is actually desired in the preparation of the matter other than the material language matter that made not calculate the time allocation of the problem so that the problem should be given a long time even made short time and vice versa. This happens because students do not understand the level of difficulty question as described in the previous discussion. As a result of not understanding the level of difficulty about the essay, the essays made cannot be a means for students to train capability think especially highorder thinking skills.

The results are in line with the opinion of [6], about the problem of the preparation of tests that often occur in teachers at junior high school (SMP) generally made by teachers less attention to the level of validity and reliability. This is because teacher-made tests cover only limited material. As a test that serves to measure the ability, then a standard test must have a degree of validity and reliability according to a series of trials, and has a high degree of difficulty and high power.

The ability of students to prepare essays in accordance with the competence and learning objectives after learning process of evaluation of education after the learning process is shown in Table II and III where $3.33 \%$ category is good enough, $13.33 \%$ with good category and $83.33 \%$ category is very good. The results showed that there was a significant increase between the problems and the ability of students before and after lecturing activities.

Other research results show that there is an increase in the ability of students in terms of preparing essays where above $80 \%$ are in good category and very good. This means that over $80 \%$ of students experience an increase in understanding in terms of essay preparation, especially related to indicators of conformity with the goals / indicators of learning, conformity with learning materials, have a level of difficulty that refers to cognitive ability, using the standard Indonesian language, in accordance with allocation of time to work, train students' thinking ability (high-level thinking ability), Table III.

The results of this study are in line with the opinion of [7], that evaluation should measure what should be measured by using reliable or valid test types, meaning that the suitability of the measuring instrument with the measurement function and the measurement target. If the measuring instrument does not have validity that can be accounted for the data will be generated will be wrong and produce conclusions that have become wrong. Evaluation must have the achievement of the competence of learners that include a set of knowledge, attitudes, skills and values reflected in habits of thinking and acting. On the basis of this competence, the measures of successful learning will be known clearly and directed.

Evaluation should be done continuously from time to time to thoroughly understand the progress of the learners, so that the activities and performance of learners can be monitored through assessment. Evaluation should be done thoroughly, covering the aspects of cognitive, affective, and psychomotor and based on strategies and assessment procedures by sharing evidence of learners' learning outcomes that can be accountable to all parties.
Evaluation is expected to have meaning which is significant for all parties. For that evaluation should be easily understood and can be followed up by the parties concerned. Evaluation should consider the sense of fairness and objectivity of learners, regardless of gender, ethical background, and culture. Because the injustice in the assessment can lead to decreased motivation learners learn because they feel beaned.

Evaluation should be open to the various circles so that the decision about the success of the learners is clear to the parties concerned, without any engineering and stealth. Sincere is the success of the intention or heart of teachers or educators, that he in doing the evaluation in order to achieve efficiency education and interests of learners themselves. Practical means easy to understand and implemented with several indicators, such as; saving time, cost, effort, easily administered easily scoring and managing it, and easily interpreted. The results of each learner's evaluation must be systematically and comprehensively recorded and stored, so that they can be reused at any time.

The results showed the problems faced by students related to the preparation of essay questions in accordance with the competence and objectives of learning after the learning process of evaluation after the lecture was conducted where $13.33 \%$ of the students had problems with the Conformity with the Learning Objectives / Indicators $6.66 \%$ of the Problem students Conformity With the Material Lessons Learned, $16.66 \%$ of Problematic Students Associated with Levels of Difficulties Referring to Cognitive Ability, 6.66\% of problem students use Raw Bahasa Indonesia, 3.33\% of troubled students are related to Time Allocation To Work, $13.33 \%$ of problem students Related to Train Student Thinking Ability (Higher Thinking Ability)

The results of this study indicate that the problems faced by students before the lecture with after the lecture there is a significant decrease above $80 \%$ problematic students while after the lecture course lived about $13 \%$ of students who are still experiencing problems. This means that if in the lecturers' process refers to the problems faced by the students before the study takes place then it can overcome the problems of students. Thus there is a link between achievements of student learning outcomes with lecture strategies used by lecturers.

The lecture procedure as an effort to improve student ability in preparing the related questions of competence and learning objectives as follows: The research procedure begins by implementing the initial recovery as much as 1 meeting to explain the way of making essay problems, and continued with the division of activity of making essays to each group to be presented as a result of performance to be presented at subsequent meeting courses Evaluation of learning by using power point learning media with learning scenarios in lectures as follows:

\section{- Initial Activity (10 minutes)}

Lecturers carry out apperception and motivation activities related subject matter Evaluation of learning. After this activity is carried out by showing the topic of the lecture followed by the sharpening of the delivery of competence or the purpose of 
the lecture which became the achievement of the student after the lecture of each lecture topic at each meeting is completed.

- Core Activity (70 minutes)

a. Lecturers conduct short lectures as part of the exploration phase in lectures referring to the topic of lecture meeting to be held (10 minutes)

b. Students are given the opportunity to present the results of the discussion in the group that is the result of the essay matter performance by utilizing the media power points (20 minutes). Elaboration phase

c. As part of the elaboration phase and the confirmation phase, students from other groups who did not receive a presentation turn were given the opportunity to present responses and questions to the group presenting with moderator guides from the group conducting the presentation. this activity is done through discussion method (25 minutes)

d. Lecturers carry out facilitation activities by referring to the achievements and development of lecture materials and provide last chance to students who will still ask or respond, are part of the elaboration and confirmation phase (15 minutes)

\section{- Final Activity (10 minutes)}

a. The group that gets the presentation turn makes a conclusion on the topic of lectures that refers to the objectives or competencies of lecture topic achievement with faculty facilitation, part of the confirmation phase.

b. The lecturers give rewards to the group that perform the presentation and deliver the task related to the material of the next lecture meeting to the group who got the presentation turn.

\section{- Assessment Procedure}

The assessment procedure for obtaining student learning outcomes which, in this case is measured through the performance results of essays, refers to the results of the performance activities performed independently by the students assigned by the lecturer at the end of each lecture meeting, which refers to the topics undertaken by each group on during the presentation of formal and non-formal education

The problem faced by approximately $13 \%$ of students after the lecture is located in conformity with the goals / indicators of learning, $6.66 \%$ of students with problems in conformity with learning materials, has a level of difficulty that refers to cognitive abilities, using the standard Indonesian language, related with time allocation to train students' thinking ability (high-level thinking ability). Thus, lecturers need to do special enrichment activities to the students related to the problem.

This is in line with the function of evaluation as revealed by $[8,9]$. In general, evaluation as an action or process has at least three main functions, (1). Measure progress, (2). Support the preparation of the plan, and (3). Fix or refine.

\section{CONCLUSION}

Referring to the results of research and discussion of the findings of this study it can be concluded several things as follows:

1. Problems faced by students related to the preparation of essay questions in accordance with the competence and objectives of learning before the process of learning evaluation of education $80 \%$ of students have problems with Conformity with Learning Objectives / Indicators $80 \%$ of Problem students Compliance with Learning Materials $80 \%$ Referring to Cognitive Ability $80 \%$ of troubled students use Raw Bahasa Indonesia, $80 \%$ of troubled students are related to Time Allocation To Work, $80 \%$ of students have problems related to Student Thinking Ability (Higher Thinking Ability).

2. Ability of students to prepare essays in accordance with the competence and objectives of learning after the process of learning evaluation of education $80 \%$ Conformity With Learning Objectives / Indicators, 80\% Conformity With Learning Materials 13\% of Problematic Students Associated with Levels of Difficultness Referring to Cognitive Ability $80 \%$ using Raw Indonesian, 80\% Appropriateness With Time Allocation To Work, $13.33 \%$ Train Student Thinking Ability (Higher Thinking Ability).

3. Problems faced by students related to the preparation of essay questions in accordance with the competence and objectives of learning after learning evaluation process of learning $13.33 \%$ of students in trouble with Conformity with Learning Objectives / Indicators 6.66\% Problem students Conformity With Learning Materials $16,66 \%$ the problematic students are related to having the Depth of Difficulties Referring to Cognitive Ability, $6.66 \%$ of problem students use Raw Bahasa Indonesia, 3.33\% of problem students are related to Appropriateness Time To Work, $13.33 \%$ of students with problem related to Train Ability of Student Thinking ( Higher Thinking Skills).

Based on the conclusion then there are some suggestions for the problems related to making the insectarium can be minimized, as for the suggestion as follows:

1. Before the lecture should lecturers have known the basic problems faced by students related to the making of essay so that this problem should be focused by the lecturer to be overcome during lectures.

2. In the lecture so the lecturer refers to the technique of measuring the evaluation of the direct accompanied by guided training through the process of presentation in each lecture meeting.

\section{REFERENCES}

[1] K. Tasopoulou and G. Tsiotras, "Benchmarking towards excellence in higher education," Benchmarking: An International Journal, vol. 24 Issue: 3, pp. 617-634, 2017.

[2] A. Bruno and G. Dell'Aversana, "Reflective practicum in higher education: the influence of the learning environment on the quality of 
practice," Higher Education Research \& Development, vol. 36, 2017 learning," Assessment \& Evaluation in Higher Education, vol. 26 Jun 2017, pp. 1-14, 2017.

[3] Haviluddin, A. Sunarto, and S. Yuniarti, "A Comparison between Simple Linear Regression and Radial Basis Function Neural Network (RBFNN) Models for Predicting Students' Achievement.," in International Conference on Education 2014 (ICEdu14) 4th - 6th June 2014., Universiti Malaysia Sabah - Kota Kinabalu, Malaysia, 2014, pp. 299-308.

[4] O. Pey-Tee, B. Spencer, and C. C. Seng-Kam, "Psychometric quality of a student evaluation of teaching survey in higher education," Assessment \& Evaluation in Higher Education, vol. 42, 2017 - Issue 5, pp. 788-800, 2017.

[5] C. Englund, A. D. Olofsson, and L. Price, "Teaching with technology in higher education: understanding conceptual change and development in Issue 1, pp. 73-87, 2017.

[6] C. D. Eaton, D. Allen, L. J. Anderson, G. Bowser, M. A. Pauley, K. S. Williams, and G. E. Uno, "Summit of the Research Coordination Networks for Undergraduate Biology Education," 2016.

[7] Ramayulis. (2008). Metodologi Pendidikan Agama Islam.

[8] P. Brickman, C. Gormally, and A. M. Martella, "Making the Grade: Using Instructional Feedback and Evaluation to Inspire Evidence-Based Teaching," 2016.

[9] M. L. Aikens, L. A. Corwin, T. C. Andrews, B. A. Couch, S. L. Eddy, L. McDonnell, and G. Trujillo, "A Guide for Graduate Students Interested in Postdoctoral Positions in Biology Education Research," 2016. 